\title{
Commodity Systems Assessment Methodology of Postharvest Losses in Vegetable Amaranths: The Case of Tamale, Ghana
}

\author{
Mildred Osei-Kwarteng, ${ }^{1}$ Joseph Patrick Gweyi-Onyango, ${ }^{2}$ and Gustav Komla Mahunu' \\ ${ }^{1}$ Department of Horticulture, Faculty of Agriculture, University for Development Studies, P.O. Box TL 1882, Tamale, Ghana \\ ${ }^{2}$ Department of Agricultural Science and Technology, Kenyatta University, P.O. Box 4384400100, Nairobi, Kenya \\ Correspondence should be addressed to Mildred Osei-Kwarteng; misokwart@yahoo.com
}

Received 23 January 2017; Accepted 5 March 2017; Published 20 March 2017

Academic Editor: Allen Barker

Copyright (c) 2017 Mildred Osei-Kwarteng et al. This is an open access article distributed under the Creative Commons Attribution License, which permits unrestricted use, distribution, and reproduction in any medium, provided the original work is properly cited.

\begin{abstract}
A semistructured questionnaire based on the commodity system assessment methodology (CSAM) was used to determine postharvest losses in vegetable amaranths (VA). Fifty producers and retailers were randomly selected from five and four major VA producing areas and markets, respectively, and interviewed. Data obtained were subjected to descriptive statistical analyses. The survey revealed that absence of laws, regulation, incentives, and inadequate technical information affected the production of VA. The utmost preproduction challenge was poor quality seeds with poor seed yield (35\%), low viability (19\%), and nontrueness (46\%). It was noted that some cultural practices including planting pattern and density, irrigation, and fertiliser use had effects on postharvest losses. Some postharvest practices used were cleaning with water, trimming, sorting, and grading. Usually the produce was transported to marketing centers by cars and motor cycle trailers. Generally poor temperature management after harvest was a big challenge for the postharvest handling of VA. The potential of vegetable amaranths as a commodity in the study area can be enhanced by providing the necessary institutional support, incentives, and use of good management practices along the value chain. An interdisciplinary approach and quantification of losses along the chain are recommended for any future study.
\end{abstract}

\section{Introduction}

In Ghana, it is estimated that about $20-50 \%$ of vegetables produced are lost due to preharvest and postharvest factors, including cultural practices (e.g., fertilisation, water supply, and harvesting method) and poor postharvest handling [1,2]. In developing countries (e.g., Benin), postharvest losses in vegetable amaranths can be as a high as $79-89.5 \%$ due to damage and decay $[3,4]$ resulting from poor handling and storage facilities [5].

Commodity systems assessment methodology (CSAM) is a postharvest loss assessment procedure that was originally developed and modified over years [6,7]. This method evolved as a result of the perceived need for a systematic approach to identify, prioritize, and resolve postharvest problems from planning to product distribution to ensure that all factors affecting a given commodity are considered along the value chain. The CSAM covers two major aspects of the value chain, preharvest (preproduction and production) and postharvest (harvesting and marketing) [6, 7].
An important feature of this methodology is that, with 26 components (Figure 1), it permits an analysis of a whole commodity system, thus facilitating the identification and prioritization of problems throughout the system. The CSAM was employed to assess postharvest losses of about 16 crops including leafy vegetables in South Asia (India) and subSaharan Africa (Benin, Ghana, and Rwanda) and for other crops worldwide as a first step towards the reduction of food losses and improve the efficiency and productivity of the value chain of these commodities $[7,8]$.

Amaranths (Amaranthus spp. L.) are widely grown in the tropics as one of the most important leafy vegetables in the lowlands of Africa and Asia but have a short postharvest shelf life of 1-2 days [9]. Grubben and Denton [10] noted the economic value of amaranths as the main African leafy vegetable ranking high in terms of quantity and area under cultivation. They are recognized as an easy-to-grow, extremely productive, and nutritious vegetable and probably the highest yielding leafy vegetable in the tropics. The protein, vitamin $\mathrm{A}$, vitamin $\mathrm{C}$, calcium, iron, and zinc content in the leaves 


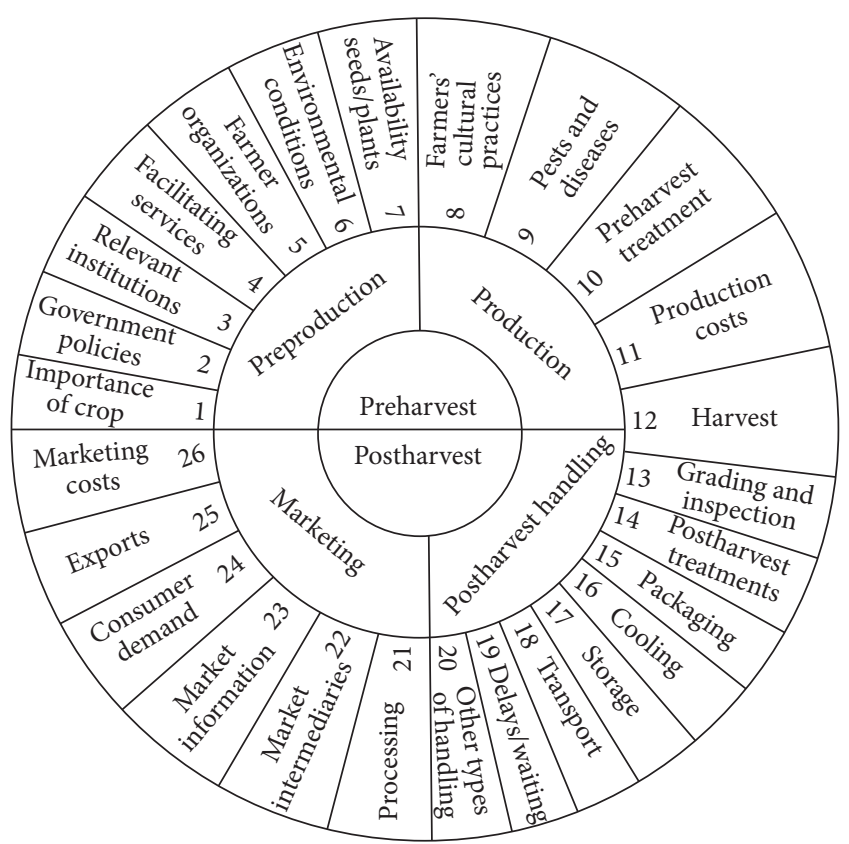

Figure 1: Components of the CSAM $[6,7]$.

per $100 \mathrm{~g}$ edible portion are $3.2-4.6 \mathrm{~g}, 1.7-5.7 \mathrm{mg}, 36-64 \mathrm{mg}$, 270-582 mg, $2.4-8.9 \mathrm{mg}$, and $0.7-1.5 \mathrm{mg}$, respectively [11]. Their excellent nutritional values make them important for human nutrition, both in rural areas for home consumption and as cheap green vegetable in cities [10]. It was also noted by Osei-Kwarteng et al. [12] as the indigenous leafy vegetable (ILV) with the highest market share in Tamale metropolitan area. The above qualities enhance their potential for nutrition sensitive agriculture and therefore the need for systematic analysis of the postharvest losses of vegetable amaranths. Moreover, ILVs that are adapted to the agroecological zones of Northern Ghana are to be promoted towards food security, eradication of malnutrition, and poverty reduction. A simplified survey was conducted to assess the contribution of the preproduction, production, postharvest, and marketing activities on the postharvest losses of vegetable amaranths. The output from the CSAM will synthesize information which can be used to improve the value chain of vegetable amaranths and food security in the study area.

\section{Material and Methods}

The survey was conducted in Tamale (Figure 2), the northern regional capital of Ghana, which lies between latitude $9^{\circ} 15^{\prime}$ and $9^{\circ} 05^{\prime} \mathrm{N}$ and longitude $0^{\circ} 45^{\prime}$ and $1^{\circ} 0^{\prime} \mathrm{W}$ and at an altitude of $185 \mathrm{~m}$ above sea level and its suburban areas. The investigation was conducted between May and June 2012. Two separate semistructured questionnaires based on the components of the commodity systems assessment methodology [CSAM, [6]] were used in interviewing 50 producers and 50 retailers of vegetable amaranths. Simple random sampling technique [13] was used in selecting the respondents for the survey. This study concentrated on preharvest (preproduction and production) and postharvest (postharvest handling and marketing) components of the CSAM for the assessment of losses in vegetable amaranth production. The selected respondents were from five major vegetable producing areas (Datoyili, Bulpiela, Gumbihini, Manguli, and Sangani) and four major markets (Tamale Central, Lamashegu, Kukuo, and Aboabo markets; Figure 2).

Some of the issues considered in the survey instrument were (i) preproduction: relative importance of the crop, governmental policies, relevant institutions, facilitating services, producer/shipper organizations, environmental conditions, and availability of planting materials; (ii) production: farmers' general cultural practices, pest and diseases, preharvest treatments, and production cost; and (iii) postharvest: harvest, grading, sorting and inspection, postharvest treatments, packaging, cooling, storage, transport, delay or waiting, agroprocessing, market intermediaries, market information, consumer demand, and exports. However the study did not quantify the losses within the product value chain.

Data obtained from the survey were subjected to descriptive statistical analyses using the Statistical Package for Social Sciences (version 17.0) software.

\section{Results and Discussion}

3.1. Preproduction. Vegetable amaranth is the most cultivated indigenous vegetable in Tamale metropolitan area as reported by Osei-Kwarteng et al. [12]. The reasons why producers cultivated vegetable amaranths included high demand (33\%), high profit (32\%), low initial capital (25\%), and fast growth (20\%). The importance of the crop is further deepened by its relative contribution to the local diet and livelihoods of the people. These are corroborated by the report of Ngugi et al. [14] which stated that, in urban centers in Kenya, there is high demand for African indigenous vegetables (AIVs) due to their nutritional and medicinal values.

The survey noted the nonexistence of laws, regulation, or incentives supporting the production of vegetable amaranths due to the fact that (1) they are relatively less important in the crop production system in Ghana and consequently ignored by development and government agencies [15], (2) there is less research focus [15], and (3) information on the quantities cultivated and their urban demand structure is inadequate $[16,17]$ since they are minor crops that contribute little to the livelihoods and nutrition of people. Shackleton et al. [18] reported that policies on ALVs are absent or weak in sub-Saharan Africa (SSA) countries because they are a subset of agricultural crops and are considered under general agricultural policies. They can only have specific policy considerations when their advantages are evident by numerous research [18]. Hence, it is not surprising to find an absence of policy on vegetable amaranths in Ghana in spite of their high market share among the indigenous leafy vegetables in the Tamale metropolitan area [12]. Moreover, relevant government and nongovernment agencies work on major mandated crops or principal fruits and vegetables such as tomatoes, pepper, onions, okra, and eggplant. A review on the food and agriculture policies in Ghana a decade ago confirmed lack of comprehensive national policy document on underutilized plant species including amaranths [19]. 

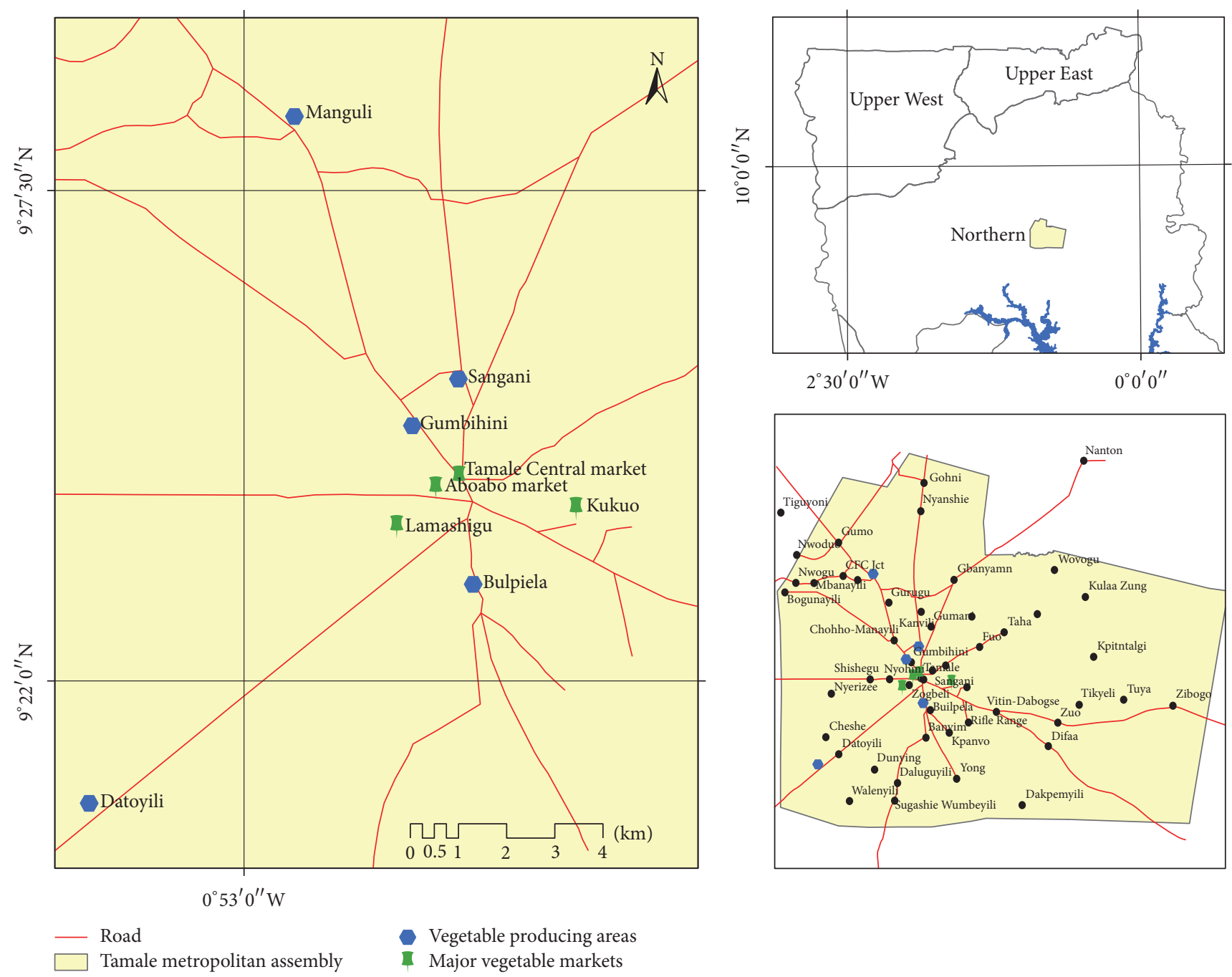

FIGURE 2: Map of Tamale metropolitan area showing major vegetable producing areas and markets.

However, the study showed that the support from nongovernmental organizations (NGOs) is noteworthy as producers (24\%) cited the German Technical Service (GIZ) for technical support whiles less of that came from the Ministry of Food and Agriculture (4\%). In the Upper East Region (Bongo district), the World Vision International provided extension support for indigenous leafy vegetables (ILVs) production while Adventist Development and Relief Agency (ADRA), Catholic Diocese and Action Aid Ghana, supported infrastructure development (dams) for the production of ILVs including vegetable amaranths [15]. TRAX Ghana also trained ILVs farmers in the Bongo district on soil and water conservation technologies [15]. The support given by the NGOs is based on the importance (commercial potential) of ILVs including amaranths to the livelihoods of the people in the communities.

Results from the investigation also indicated that producers obtained seeds from either the local market (35\%) or their own farms (65\%). However, it was noted that the quality of the seeds was not reliable due to poor seed yield (35\%), low viability (19\%), and being not true to type (46\%).
Similarly, in Upper East Region $10-80 \%$ of the farmers obtained seeds for ILVs including amaranths from the market [15] and our findings on amaranth seeds corroborate their observation. Hence farmers suggested that the availability of quality seeds will moderate this challenge. The source of seeds for amaranth production affirms the existence of two parallel seed systems in Ghana (traditional/informal and formal) [20]. Absence of improved and standard seeds for ILVs including amaranths was also observed in the South African Development Community region (Tanzania, Zambia, and Botswana) [17] and Kenya [21]. Generally, the nonexistence of improved seeds for the cultivation of African ILVs is a major challenge to the broad production of ILVs in Africa including Ghana, as farmers use their own seed from unselected planting materials mostly without any quality and standard criteria and technical supervision [20, 21]. Additionally, farmers own and purchased seeds which may be poorly handled at storage and consequently affect the vigour and germination percentage [20]. These seed constraints indicate the need for research and improvement of seed sources or delivery system [19] for vegetable amaranths. 
The environmental and other constraints that were recognized by the producers as affecting the quality of their produce included insect damage (48\%), water shortage $(6 \%)$, low soil fertility (18\%), and low yields (28\%). Producers could not identify the type of insect pest that damaged their produce but reported holes in the leaves which reduced the quality of leaves. ILVs are reported to be tolerant to local pest and disease [22] and in Southeast Asia [23] amaranths are also noted to have no serious insect pest, disease, and nematodes [24] attack. However, there is an expected pest build-up in hot and humid climates when an intensive monoculture is regularly practiced [18]. Moreover, in some West African countries insect pests and disease have been found on amaranths [23]. Hence in regular production, producers must practice safe and effective integrated pest management methods [22] before or after production to reduce postharvest loses. An avoidable loss of $20 \%$ in vegetable amaranths was estimated in Kenya as caused by insect pests [22]. Inadequate water supply during production induces flowering and reduces the leave yield in vegetable amaranth [25]. Vegetable amaranths do best on fertile well-drained deep soils although they are adapted to a variety of soils including marginal soils [25].

3.2. Production. The study revealed that all the producers were conversant with production practices that affect produce quality. They listed planting density and pattern, weed, pest and disease control, irrigation, and fertiliser use as familiar practices. They also observed insect pests that made holes in the leaves. This knowledge is based on the experience gained over the years. Conversely, they could not identify viral and fungal infections. Previous reports on the postharvest losses of 16 commodities including leafy vegetables showed that farmers used some production practices that increased the challenges of postharvest quality and losses of these crops [26]. Vegetable amaranths are usually grown commercially as a sole crop and intercropped with food crops in home gardens [27]. Most farmers plant at a density of 180 plants $/ \mathrm{m}^{2}$ for single harvest by uprooting the whole plant but a plant density of $100 \mathrm{plts} / \mathrm{m}^{2}$ is strategic for good quality produce. If the desire is several harvests during the season then vegetable amaranths should be planted at $20 \mathrm{plts} / \mathrm{m}^{2}$ [27]. Generally good cultural practices specific for vegetable amaranths are recommended for good quality produce at harvest for immediate consumption or further handling.

Ninety-two percent (92\%) of the producers harvested themselves in the morning by cutting with sharp knives or by uprooting. Harvesting with sharp knives avoids severe abrasions or bruises that occur with blunt knives which opens up entry points for microorganisms and hastens the rate of produce decay [7] while physical damage causes 34 times more moisture loss than undamaged produce [8]. Other types of equipment used during harvesting include baskets, basins, sacks, and fiber and fertiliser bags. Majority of farmers (54\%) used the number of nodes and branches as an indicator of maturity. Additional determinants of maturity were plant height (27\%) and canopy spread (19\%). Vegetable amaranths can be harvested between 30 and 55 days after sowing at a height of $60 \mathrm{~cm}$ when leaves are young and slender [25]. Harvesting at the right physiological age prevents the rapid loss of quality of the produce, since at the appropriate harvest maturity, leaves are less prone to moisture loss and subsequent wilting [8]. Leafy vegetables harvested at early hours (0400 hrs) and late hours (2000 hrs) contained higher water potential which reduces the rate of water loss. Moreover, produce harvested late in the day has high sugar levels due to the photosynthesis in the day [8]. At late harvesting, leafy vegetables become fibrous and lose their tenderness [7]. Poor packaging materials such as baskets, basins, and sacks easily make the produce prone to damage from bruises and further allow entry of microorganism during transport and storage. Additionally, leafy vegetables are easily stressed in such packaging material during storage and transport [7].

3.3. Postharvest. The postharvest practices used by farmers were cleaning (66\%), trimming (34\%), and cooling either under shady trees in the ambient air (25\%) or with cool water $(75 \%)$ at ambient temperature. The problem with cooling under ambient air conditions is that temperature increases within the piled produce with time. In this case, the respiration rate of the piled produce increases resulting in water and weight loss and thus reduces the market value [8]. Cooling of produce is done immediately after harvest on farms. Two basins of cool water are used for washing the produce after harvesting; roots are washed in the first basin and the harvested shoots are washed in the second basin. Subsequently cool water is sprinkled on the day's harvest and stacked in containers for transportation. Washing all produce in the same basin may contaminate the produce with soil or plant pathogens which will facilitate postharvest diseases [8]; hence for good sanitation practices, produce should be washed in clean water. At the market, produce is also cooled again by sprinkling water on display. Unsold produce is also sprinkled with water to maintain the freshness for the next day. In spite of the above cooling practices, stacking or piling of produce in containers (woven baskets and pans) during transport or storage renders the whole practice ineffective. Temperature management after harvesting is to avoid a high ambient temperature which reduces the quality of produce and the market value after harvest [8]. The high mean day time temperatures $\left(28-43^{\circ} \mathrm{C}\right.$ [28]) of the Tamale metropolitan area demand a good cooling system for the harvested produce.

Retailers stored produce in their stalls, while producers stored produce either at shady places $(46 \%)$ or in their kitchen or hut (54\%) at ambient temperature. In these storage situations the produce experiences fluctuating temperature which affects the stability of the quality and acceptability of the produce by the consumers. Freshly harvested vegetable amaranths can be maintained at a temperature of $0-2^{\circ} \mathrm{C}$ and relative humidity of $95-100 \%$ for 14 days [29]. Vegetable amaranths packaged under modified atmospheric conditions (active bags) and stored at $5^{\circ} \mathrm{C}$ at $75 \%$ relative humidity could be stored for 23 days with about $55 \%$ retention of ascorbic acid compared to the control sample stored at room temperature $\left(25^{\circ} \mathrm{C}\right)[5]$.

Middlemen transports produce by using cars (57\%) and motorcycle trailers (motor king in Ghana; 43\%). Producers transports produce by either head porting $(34 \%)$ or 
motorcycle trailers (65\%). During transport fresh produce is stressed by packing them tightly so as to have more room for more produce. Nevertheless the atmospheric conditions (e.g., high temperature and low relative humidity) during transport also increases the respiration rates which result in weight loss of the produce as tissues lose turgor and succulence [30].

Delay in transporting produce to marketing centers can be at least 2 hours (43\%) and a maximum of 6 hours (36\%). Fifty-eight percent (58\%) of middlemen registered delay in transportation. Delays were attributed to vehicular breakdown (30\%), heavy rains $(16 \%)$, and sheer delay by drivers, retailers, and producers (54\%). Because harvested produce are transported under high ambient temperatures and also piled, such delays are to be avoided.

Retailers were very particular about grading and sorting in the market for better pricing. This indicates that the consumers are not only particular about price but also some standard for quality produce [7]. Thirty-two percent of retailers stated the inadequacy of labour for grading and sorting when they have large volumes of produce, while $68 \%$ did not see that as a problem because they are sorted and graded by themselves. Few (6\%) of handlers $(6 \%)$ are well trained in sorting and grading but the retailers first demonstrate how their hired labour should do the activity.

There was no processing method for harvested produce other than the drying and grinding of dried leaves in the study area. Drying is not mostly done because consumers have preference for fresh produce for their soups and sauces. All actors emphasized the urgent need for simple innovative agroprocessing methods during the glut period. Traditional drying in the sun can be improved by using affordable solar drying methods which avoid possible incomplete or uneven drying that allows microbial growth and prevents loss of nutritional quality (vitamins and minerals) [30, 31]. Processing freshly harvested vegetable amaranths can reduce postharvest losses of about $20-50 \%$ within the value chain [31]. Processing methods such as solar drying and freeze drying are recommended for the upgrading of vegetable amaranths into supermarkets in Tamale.

Twenty percent of retailers indicated that they are able to handle produce for 2 days while the majority $(80 \%)$ can do so in a day because of the perishable nature of the amaranth leaves. Vegetable amaranths displayed in the market have a short postharvest shelf life due to the hot environmental conditions and no cooling facilities.

Packaging materials for transport and storage of produce are basins (30\%), baskets (28\%), polyethylene bags ( $26 \%)$, and sacks $(16 \%)$ which are not highly conducive for the purpose. Therefore the need for an appropriate packaging material will protect the produce from damage, preserve the quality, and enable good ventilation to avoid the accumulation of heat and/or unwanted gases in the produce [29].

3.4. Marketing. Seventy-six percent of retailers indicated that producers set prices at the beginning of the production period to ensure that price per unit weight is similar throughout the production area. This implies that producers are well organized and take decisions that make them benefit from their produce. Producers do not have any formal means of getting market information other than visiting the markets themselves. However, they are mostly informed on trends and consumer demand in the market by the retailers and middlemen who mostly come to their farms to harvest purchased plots or harvestable produce. Retailers also decide on market prices from the prevailing farm gate price.

Retailers (64\%) indicated that consumers preferred the produce bundled while $36 \%$ desired loosely packed portions. Out of the retailers who indicated consumer preference for bundled produce, $52 \%$ observed that consumers normally like smaller bundle sizes compared to $48 \%$ who like bigger bundles. Fresh dark green leaves were much preferred. The smaller bundle sized produce is mostly for home or household use while the bigger bundle sized produce is for commercial cooking purposes. Bigger bundle sized produce is more prone to postharvest losses as there is less air circulation within the produce because it is mostly piled in basins or baskets during sales.

Almost all retailers (98\%) expressed unmet demand and oversupply of produce in some occasions. Unmet demands occurred during the dry season when produce is scarce due to water shortage (33\%) and pest and diseases (35\%). Thirty-two percent of retailers had excess supply of the produce in the wet season resulting in cheaper farm gate prices but maintained their prices and rather increased the size of the bundles for the same price. This suggests the need to process into other forms to avoid losses in the wet season. Consumers rather looked out for high quality produce (undamaged and dark green) during the wet seasonal glut. Producers confirmed that amaranth leaves are not exported; as such there is no existing regulation on its trade. Producers, marketers, and consumers of vegetable amaranths wished that there could be simple postharvest treatments. Nevertheless, they preferred nonchemical and inexpensive treatments.

\section{Conclusion}

The study assessed the contribution of current practices on postharvest losses of vegetables amaranths using a commodity system assessment methodology in the Tamale metropolis, Ghana. Our investigation revealed absence of laws, regulation, and incentives for vegetable amaranth production. There is also deficiency in quality seed for production since seeds are mostly obtained from the producer's field and open markets and not subjected to any standard quality criteria. Producers had a fair understanding of the influence of some cultural practices (e.g., planting pattern and density, weed, pest and disease control, irrigation, and fertiliser use) on postharvest losses. Further, produce is transported at ambient temperature to market centers by cars or motorcycle trailers. Retailers are particular in grading and sorting of the produce to enhance pricing.

There are observed challenges at all stages of the product chain and the potential of vegetable amaranths as a commodity in the study area can be enhanced by providing the necessary institutional support and incentives. This work provides first-hand information for development planners and government and nongovernment institutions that are seeking to improve a popular indigenous leafy vegetable in 
urban communities such as the Tamale metropolitan area. Finally, the quantification of losses at each level of the chain is recommended.

\section{Conflicts of Interest}

The authors declare no conflicts of interest for this publication and that data used are from their own investigation.

\section{Acknowledgments}

The authors are grateful to Dr. Lisa Kitinoja and her Postharvest Education Foundation team for the revision of the first draft of the manuscript.

\section{References}

[1] Y. S. Gonzalez, Y. Dijkxhoorn, I. Koomen et al., "Vegetable business opportunities in Ghana," The GhanaVeg Sector Reports, 2016, http://ghanaveg.org/.

[2] I. K. Arah, H. Amaglo, E. K. Kumah, and H. Ofori, "Preharvest and postharvest factors affecting the quality and shelf life of harvested tomatoes: a mini review," International Journal of Agronomy, vol. 2015, Article ID 478041, 6 pages, 2015.

[3] H. Affognon, C. Mutungi, P. Sanginga, and C. Borgemeister, "Unpacking postharvest losses in sub-Saharan Africa: a metaanalysis," World Development, vol. 66, pp. 49-68, 2015.

[4] L. Kitinoja, "Identification of appropriate postharvest technologies for improving market access and incomes for small horticultural farmers in sub-Saharan Africa and south Asia," WFLO Grant Final Report, 2010.

[5] J. A. Nyaura, D. N. Sila, and W. O. Owino, "Postharvest stability of vegetable amaranths (Amaranthus dubius) combined low temperature and modified atmospheric packaging," Food Science and Quality Management, vol. 30, pp. 66-72, 2014.

[6] J. La Gra, A Commodity Systems Assessment Methodology for Problem and Project Identification, Postharvest Institute for Perishables, University of Idaho, IICA, AFHB, Moscow, Idaho, USA, 1990.

[7] J. La Gra, L. Kitinoja, and K. Alpizar, Commodity Systems Assessment Methodology for Value Chain Problem and Project Identification: A First Step in Food Loss Reduction, InterAmerican Institute for Cooperation on Agriculture, San Isidro, Costa Rica, 2016.

[8] A. L. Acedo Jr., Postharvest Technology for Vegetables, AVDRC-ADB Postharvest Projects RETA 6208/6376, AVDRC Publication no. 10-733, AVDRC-The World Vegetable Center, Tainan, Taiwan, 2010.

[9] J. Norman, Tropical Vegetable Crops, Arthur H. Stockwell Ltd, Devon, UK, 1992.

[10] G. J. H. Grubben and O. A. Denton, Eds., Plant Resources of Tropical Africa 2: Vegetables, PROTA Foundation, Wageningen, The Netherlands; Backhuys Publishers, Leiden, The Netherlands; CTA, Wageningen, The Netherlands, 2004.

[11] E. G. Achigan-Dako, O. E. D. Sogbohossou, and P. Maundu, "Current knowledge on Amaranthus spp.: research avenues for improved nutritional value and yield in leafy amaranths in subSaharan Africa," Euphytica, vol. 197, no. 3, pp. 303-317, 2014.

[12] M. Osei-Kwarteng, G. K. Mahunu, and E. Yeboah, "Baseline survey on the seasonal market share of exotic and indigenous leafy vegetables produced, sold and consumed in Tamale, Ghana," Ghana Journal of Horticulture, vol. 10, pp. 119-129, 2012.

[13] J. W. Creswell, Educational Research: Planning, Conducting, and Evaluating Quantitative and Qualitative Research (4th edn.), Pearson Education, Inc., Boston, Mass, USA, 2012.

[14] I. K. Ngugi, R. Gitau, and J. Nyoro, Access to High Value Markets by Smallholder Farmers of African Indigenous Vegetables in Kenya, Regoverning Markets Innovative Practice Series, IIED, London, UK, 2007.

[15] ICRA/CBUD, Indigenous Leafy Vegetables in the Upper East Region of Ghana: Opportunities and Constraints for Conservation and Commercialisation, Working Document Series 102, ICRA/CBUD, Kumasi, Ghana, 2002.

[16] F. I. Smith and P. Eyzaguirre, "African leafy vegetables: their role in the World Health Organization's global fruit and vegetables initiative," African Journal of Food, Agriculture, Nutrition and Development, vol. 7, no. 3, pp. 1-17, 2007.

[17] E. Lyatuu and L. Lebotse, Eds., Marketing of Indigenous Leafy Vegetables and How Small-Scale Farmers Can Improve Their Incomes, Agricultural Research Council, Dar es Salaam, Tanzania, 2010.

[18] C. M. Shackleton, M. W. Pasquini, and A. W. Drescher, "African indigenous vegetables in urban agriculture: recurring themes and policy," in African Indigenous Vegetables in Urban Agriculture, C. M. Shackleton, M. W. Pasquini, and A. W. Drescher, Eds., pp. 271-283, Earthscan, Routledge, UK, 2009.

[19] Council for Scientific and Industrial Research Ghana/Global Facilitation Unit for Underutilized Species, "Underutilized plant species strategies and policies. Analysis of existing national policies and legislation that enable or inhibit the wider use of underutilized plant species for food and agriculture in Ghana," Report 2007, http://www.underutilizedspecies.org/record_details_id_836.html.

[20] P. M. Etwire, I. D. K. Atokple, S. S. J. Buah, A. L. Abdulai, A. S. Karikari, and P. Asungre, "Analysis of the seed system in Ghana," International Journal of Advance Agricultural Research, vol. 1, pp. 17-13, 2013.

[21] M. O. Abukutsa-Onyango, "Seed production and support systems for African leafy vegetables in three communities in western Kenya," African Journal of Food Agriculture Nutrition and Development, vol. 7, no. 3, pp. 1-16, 2007.

[22] M. O. Oluoch, G. N. Pichop, D. Silué, M. O. AbukutsaOnyango, M. Diouf, and C. M. Shackleton, "Production and harvesting systems for African indigenous leafy vegetables," in African Indigenous Vegetables in Urban Agriculture, C. M. Shackleton, M. W. Pasquini, and A. W. Drescher, Eds., pp. 145170, Earthscan, London, UK, 2009.

[23] G. J. H. Grubben, The Cultivation of Amaranths as a Tropical Leaf Vegetable with Special Reference to South-Dahomey, Communication 67 of the Department of Agricultural Research Koninklijk Instituut voor de Tropen, Amsterdam, Netherlands, Royal Tropical Instistute, 1976.

[24] J. E. Knott and J. Deanon, Vegetable production in SouthEast Asia, University of the Philippines Press, Metro Manila, Philippines, 1967.

[25] Production Guidelines, "Amaranthus," Department of Agriculture, Forestry and Fisheries. 2010, http://www.nda.agric.za/ docs/Brochures/Amaranthus.pdf.

[26] WFLO, "Identification of appropriate postharvest technologies for improving market access and incomes for small horticultural farmers in Sub-Saharan Africa and South Asia," 
World Food Logistics Organisation (WFLO), Appropriate Postharvest Technology Planning Project. 2010, http://www .ucce.ucdavis.edu/files/datastore/234-1848.pdf.

[27] G. J. H. Grubben, "Amaranthus cruentus L.", in Record from PROTA4U. PROTA (Plant Resources of Tropical Africa), G. J. H. Grubben and O. A. Denton, Eds., PROTA, Wageningen, The Netherlands, 2004, http://www.prota4u.org/search.asp.

[28] Klimatafel von Tamales/Ghana, "Baseline climate means (1961-1990) from stations all over the world (in German)," Deutscher Wetterdienst.

[29] L. Kitinoja and A. A. Kader, Small-Scale Postharvest Handling Practices: A Manual for Horticultural Crops, Postharvest Horticulture Series No. 8E, University of California Davis, Postharvest Technology and Information Center, 4th edition, 2003.

[30] K. M. Maquire, H. T. Sabarez, and D. J. Tanner, "Postharvest preservation and storage," in Handbook of Vegetable Preservation and Processing, Y. H. Hui, S. Ghazala, D. M. Graham, K. D. Murrell, and W.-K. Nip, Eds., Marcel Dekker Inc, New York, NY, USA, 2004.

[31] S. Gupta, B. S. Gowri, A. J. Lakshmi, and J. Prakash, "Retention of nutrients in green leafy vegetables on dehydration," Journal of Food Science and Technology, vol. 50, no. 5, pp. 918-925, 2013. 


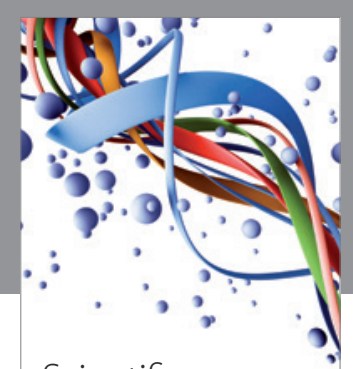

Scientifica
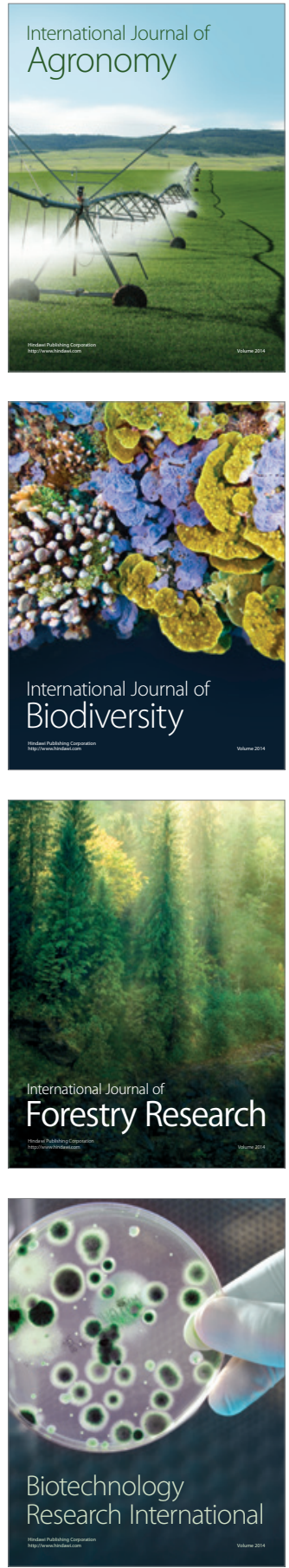
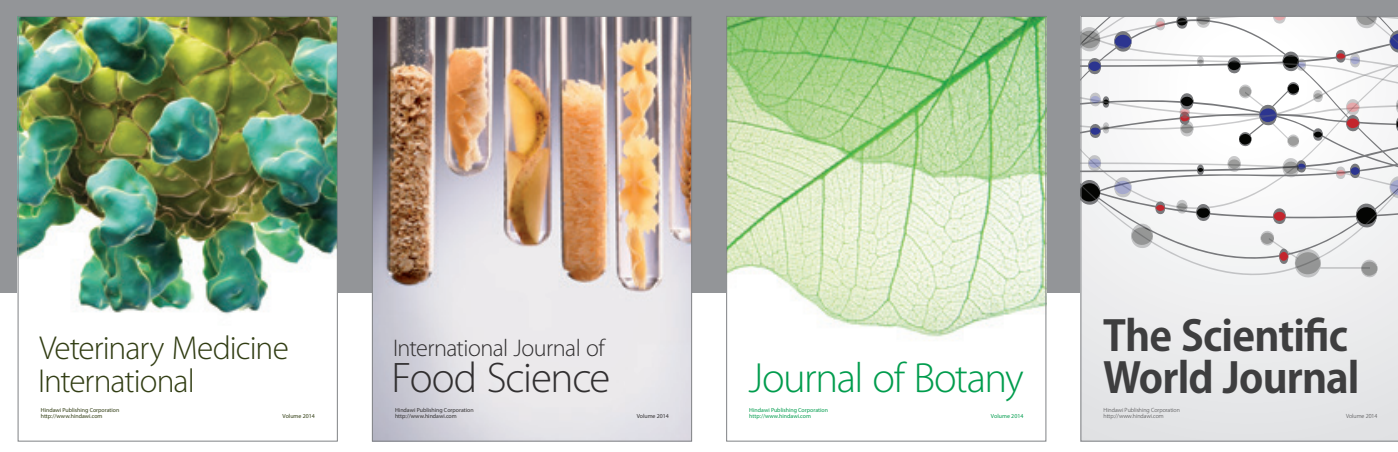

The Scientific

\section{World Journal}

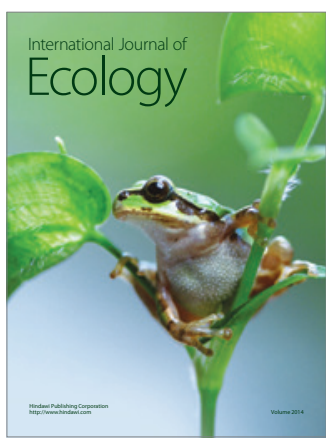

\section{Hindawi}

Submit your manuscripts at

https://www.hindawi.com
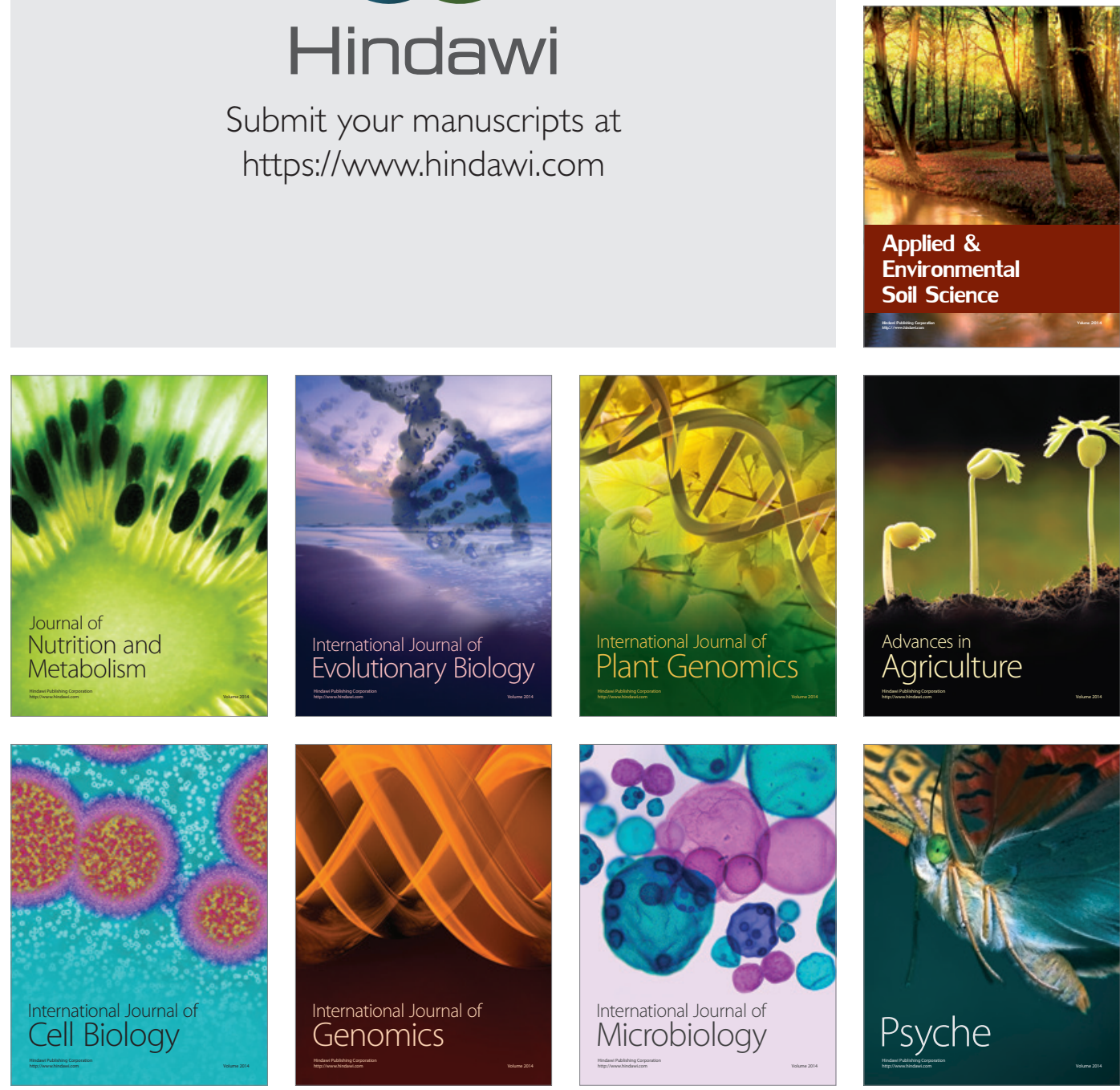
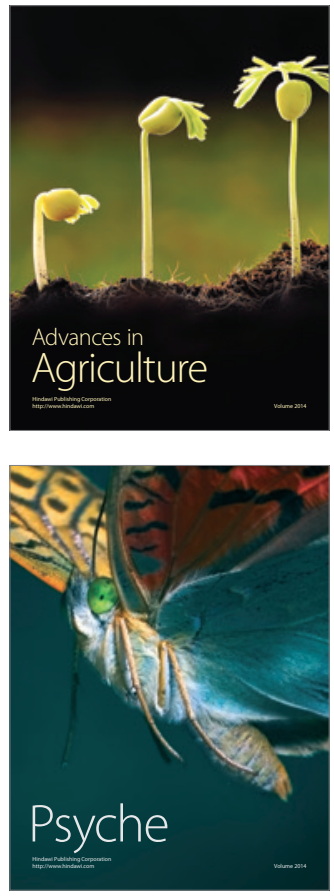